\title{
Acknowledgments
}

7 his book has its roots in the career I left when I decided to pursue graduate studies in literature. My experience as a reporter was quite different from that of the women whose experiences are chronicled here, but my first acknowledgments must go to the newspapermen and women who introduced me to the profession-the student editors at the Daily Tar Heel who taught me how to write, especially Janet Olsen and Grant Parsons, and the late Jim Shumaker, the legendary journalism professor at the University of North Carolina who assured me that going to graduate school would ruin me as a writer. (I tried to prove him wrong.) I am also grateful to my professional newspaper colleagues at the Pittsburgh Post-Gazette and the Miami Herald. The memory of their wit and dedication remains vivid, even after years away from the city room.

My research was supported by an American Fellowship from the American Association of University Women; a Villanova University sabbatical; a National Endowment for the Humanities Summer Stipend; a Mellon Fellowship from the Harry Ransom Humanities Research Center; a fellowship from the Gilder-Lehrman Institute of American History; and two awards from Manhattan College, a Summer Research Grant and a Mahony Award. A grant from the University Seminars at Columbia University helped me to prepare the manuscript for publication. I am especially grateful to Villanova University, which provided me with a supportive community, time off from teaching, and able research assistance in the person of Jana Diemer, who corrected many of my mistakes. The staff at Villanova's Falvey Library, especially Judith Olsen, often came to my aid with grace and effi- 
ciency; Donna Blaszkowski and Bernadette Dierkes in the graphics design office provided critical help with the illustrations.

Portions of this book have appeared elsewhere, and I thank the original publishers for permission to reprint. In somewhat different form, chapter 1 was published by the Johns Hopkins University Press as "Into the Madhouse with Nellie Bly: Girl Stunt Reporting in Late-Nineteenth-Century America" in American Quarterly 54, no. 2 (2002): 217-53, copyright The American Studies Association, and chapter 3 was published by Oxford University Press as "Sob Sisterhood Revisited" in American Literary History ${ }_{15} 5$, no. 3 (2003): 504-32.

My editors at Cornell University Press have been models of professionalism and patience. I am especially grateful for Sheryl Englund's early enthusiasm about the project, Alison Kalett's guidance through its final stages, and the generous and instructive commentary I received from the press's anonymous readers.

As a scholar, I have been blessed with kind and stimulating colleagues, first in graduate school at the University of Wisconsin-Madison, then at Manhattan College and again at Villanova University. For their support from the earliest days of my graduate career, I thank Katherine Adams, Emily Hall, Kirsten Jamsen, Robert Kachur, Erin Smith, and Edie Thornton. Since then, I have benefited from the insights of many other readers, including Rachel Adams, Michael Berthold, Matt Bivens, Scott Black, Ellen Bonds, Jon Connolly, Julie Crawford, Ashley Cross, Kathleen Diffley, Kim Donehower, June Dwyer, Maria Farland, Heather Hicks, Barbara Hochman, Patrick Horner, Valerie Karno, Seth Koven, John Lowney, Crystal Lucky, Rocco Marinaccio, Susannah Mintz, Hugh Ormsby-Lennon, Evan Radcliffe, Lisa Sewell, Mary Beth Simmons, Vince Sherry, Lauren Shohet, Mark and Anya Taylor, Jennifer Travis, and Liza Yukins. Rick Delano provided generous support at a crucial moment. I also appreciate the suggestions of those who heard me present my work in progress to the Columbia University Seminar on American Studies, the New York Americanist group, the Philosophy Colloquium at the University of North Dakota, and panels at meetings of the Modern Language Association, the Society for the Study of American Women Writers, and the American Literature Association. During my stay in Austin to use the Ransom Center collections, Martha Campbell was an ideal host, offering both warm hospitality and the gift of genuine curiosity about my work.

Among the many people who helped me during the years I worked on this book, two require special mention. Ashley Cross read all my early drafts, forced me to be clear even when I didn't want to be, and made me snort with laughter while sitting in the New York Public Library Reading 
Room. Rachel Adams responded to my work with patience and rigor, pinpointing its weaknesses even while she urged me on. She also cooked gloriously excessive dinners and weighed me down with leftovers for my subway trips home.

Although this book is not a revision of my dissertation, that work served as a critical foundation for what came next. I owe special thanks to Dale Bauer, who directed my dissertation, who has served as my mentor and helped me more times than I can count, and who continues to inspire me with her intellect, energy, and courage. Gordon Hutner has long been an invaluable source of professional wisdom and incisive commentary. The late Sargent Bush Jr. was an important reader, advocate, and scholarly role model. I sorely miss his integrity and wry humor.

The love of my family and friends has made my work possible and enriched my life beyond my powers to express. For this I thank Patricia Dolan; Alice, Elena, and Vivian Dueker; Nick Simon; Erin Smith; my mother, Mary O'Neil Lutes; my brothers, especially Christopher Lutes; and my sister, Beth Hillman, my earliest and most profound inspiration. Beth read every word of this book, more than once, and she has supported me in every way possible for as long as I can remember. Finally, I note my great debt to my father, Robert Blaine Lutes, who died while I was finishing the book. In recognition of his love and kindness, and because he always read the newspaper, this book is dedicated to him. 



\section{FRONT-PAGE GIRLS}


